\title{
Correlation between Oxidative Stress Parameters and Left Ventricular Geometry in Patients with Chronic Heart Failure
}

\author{
Sandra Šarić ${ }^{1}$, Tatjana Cvetkovićc,3, Dejan Petrovićn ${ }^{1,4}$, Valentina Mitić1, Sanja Stojanović1, \\ Vladana Stoiljković3 ${ }^{3}$ Marina Deljanin-Ilić', ${ }^{1,4}$
}

${ }^{1}$ Institute for Treatment and Rehabilitation "Niška Banja", Niška Banja

2University of Niš, Faculty of Medicine, Institute of Biochemistry, Niš, Serbia

${ }^{3}$ Center for Medical and Clinical Biochemistry, Clinical Centre Niš, Niš, Serbia

${ }^{4}$ University of Niš, Faculty of Medicine, Niš, Serbia

\section{SUMMARY}

Oxidative stress, as one of the pathophysiological mechanisms involved in the reduction of myocardial contractility, stimulates the proliferation of cardiac fibroblasts and the activation of matrix metalloproteinases, which leads to extracellular matrix remodeling. Left ventricular hypertrophy (LVH) is a well-known independent risk factor for cardiovascular events.

The aim of this research was to determine the connection between the parameters of oxidative stress and left ventricular geometry indicators in patients with chronic heart failure.

The study included 81 subjects diagnosed with heart failure and 68 subjects in the control group. Parameters of myocardial morphology and left ventricular function were measured by echocardiography. Thiobarbituric acid reactive substances (TBARS) content, advanced oxidation protein products (AOPP), total serum SH groups and catalase activity were performed in both groups. The results showed that there were significantly higher concentrations of TBARS, AOPP, and SH groups in patients compared to controls $(\mathrm{p}<0.01)$ and higher concentration of TBARS in patients with concentric hypertrophy compared to patients with normal geometry $(p<0.05)$. Correlation analysis showed a strong positive correlation between geometry parameters and myocardial function and TBARS and negative correlation between the right ventricule diameter and catalase activity.

The results of this study show that oxidative stress parameters are significantly elevated in patients with heart failure, and that concentrations of TBARS and AOPP - the markers of lipid and protein oxidation, strongly correlate with left ventricular geometry parameters.

Key words: chronic heart failure, oxidative stress, left ventricular geometry

Corresponding author:

Sandra Šarić

e-mail: sandrabrano.s@hotmail.com 


\section{INTRODUCTION}

Heart failure is still one of the leading health problems in the population, as well as the public health challenge with poor prognosis, as it is estimated that $2-17 \%$ of patients die during their first hospitalization, while more than $50 \%$ do not survive more than 5 years after the first hospital discharge (1).

The heart muscle undergoes adaptation to the cardiovascular event through remodeling, which leads to ventricular dilatation and a decrease in the pump's function. Oxidative stress, as one of the pathophysiological mechanisms involved in this condition, reduces myocardial contractility by modifying proteins important in the excitation process, activating various signaling kinases and transcriptional factors of hypertrophy, which leads to apoptosis (2). By stimulating the proliferation of cardiac fibroblasts and the activation of matrix metalloproteinases (MMPs), they bring about extracellular matrix remodeling.

Indicators of oxidative stress correlate closely with maximal oxygen consumption and NYHA classification of patients with heart failure $(3,4)$. A central event in chronic heart failure is a decrease in myocyte contractility, which may be due to an increase in free radical levels that disrupt the calcium cycle, alter the response of myofilaments to calcium, and alter cellular response and energy status (5). Freeradical-producing Nox-2 NADPH oxidase is crucial for the development of interstitial cardiac fibrosis leading to increased expression of pro-fibrotic growth factors and genes by enhancing NF- $\mathrm{BB}$ activation, matrix metalloproteinases, and inflammatory cell infiltration (6).

Classical stimuli for ventricular remodeling include chamber wall stress, production of inflammatory cytokines, catecholamines, angiotensin II, all of which lead to changes in cells partly through both oxidative and nitrosative stress. Free radicals lead to phenotypic changes by activating stress-dependent protein kinases, causing further hypertrophy and apoptosis (7). Free radicals also alter fibroblast proliferation, collagen synthesis and increase MMP expression (6). Although chamber remodeling may initially be an adaptive mechanism to normalize wall stress and maintain contractile function in conditions of muscle loss and volume loading, progressive chamber dilation, increased interstitial fibrosis, and arrhythmia with decreasing ejection fraction may occur over time.
Advanced oxidation protein products (AOPP), as a product of oxidative damage to proteins, can directly trigger the oxidative burst in neutrophils and monocytes (8). Together with other free radicals, it may be a signal for NFkB activation, transcription of other inflammatory mediators leading to atherogenesis, partially by oxidative modification of the LDL particle, leukocyte attraction, and smooth muscle cell proliferation.

Considering the fact that the way of geometrical and functional changes in myocardium during heart failure can affect both prognosis and treatment, the aim of our research was to determine the connection between the parameters of oxidative stress and left ventricular geometry indicators in patients with chronic heart failure.

\section{PATIENTS AND METHODS}

\section{Patients}

The research was conducted at the Institute for Treatment and Rehabilitation Niška Banja, Department of Clinical Cardiology Center for Medical and Clinical Biochemistry, Clinical Center Nis, and the Center for Biomedical Research at the Faculty of Medicine, University of Niš. The study was approved by the Ethics Committee of the Niška Banja Institute, and was conducted in accordance with the Declaration of Helsinki and good clinical practice rules. The study included 81 subjects diagnosed with heart failure. The control group consisted of 68 subjects with similar age and gender in the experimental group.

\section{Methods}

Hematological parameters of the full blood count, as well as the basic biochemical parameters, lipid status, CRP and BNP in all subject were determined by standard biochemical methods on automatic analyzers; the samples were stored at $70^{\circ} \mathrm{C}$ until biochemical analysis was performed. The value of glomerular filtration (eGFR) was determined by the MDRD formula (9).

eGFR $\left(\mathrm{mL} / \mathrm{min} / 1,73 \mathrm{~m}^{2}\right)=32788 \times(\mathrm{CRE}$ in $\mu \mathrm{mol} / \mathrm{L}^{-1,154} \times(\text { age })^{-0,203} \times(0,742$ for women $) \times$ $(1,212$ for black race subjects) 
Thiobarbituric acid reactive substances (TBARS) content, as a biomarker of oxidative stressinduced lipid peroxidation, was assayed in plasma according to the method of Andreeva (10).

An improved method for the determination of total serum $\mathrm{SH}$ groups was based on the formation of color product, monitored at $412 \mathrm{~nm}$ after addition of Ellman's reagent (5, 5'-dithiobis- 2-nitrobenzoic acid) (11).

The catalase activity was determined by the spectrophotometric method, based on the ability of hydrogen peroxide to form a stable stained complex with molybdenum salts (12).

Advanced oxidation protein products (AOPP) were determined in plasma mixed with $\mathrm{H}_{2} \mathrm{O}$, acetic acid and potassium iodide. The absorbance was read spectrophotometrically at $340 \mathrm{~nm}$ and compared to a solution of chloramine $\mathrm{T}$ dissolved in the same buffer. The data were expressed as $\mu \mathrm{mol} / \mathrm{mg}$ of chloramine $\mathrm{T}$ (13).

Parameters of myocardial morphology and left ventricular function were measured by echocardiography. Echocardiography was performed at the Echocardiography Office of the Cardiology Department of the Niška Banja Institute. All patients underwent two-dimensional transthoracic echocardiography during treatment, using available standard equipment (MyLab60) with a 2.5 Mhz probe, and were analyzed according to the current American Echocardiography Association guidelines (14).

Left ventricular end-diastolic diameter (EDD), end-systolic diameter (ESD), interventricular wall thickness during diastole (IVS), and posterior wall thickness during diastole (PWT) were measured by M-mode. From these measurements, the left ventricular mass (LVM) was calculated according to the Devereux formula $(15,16)$. Left ventricular mass index (LVMI) was calculated as the ratio between left ventricular mass and body surface area (BSA) (normal values: 43-95 g/m² for women and 49-115 $\mathrm{g} / \mathrm{m}^{2}$ for men) (15). The relative wall thickness (RWT) was calculated by dividing the sum of systole wall thickness (IVS) and posterior wall thickness (PW) by the left ventricular end-diastole dimensions (EDD). According to the ASE/EAE, RWT of 0.22 to 0.42 was regarded as normal. Using the parameters LVMI and relative wall thickness ( $\mathrm{RWT}=2^{*}$ wall thickness/enddiastolic diameter), four classes of LV geometry may be recognized: normal geometry (normal LVMI and normal RWT), concentric remodeling (normal LVMI and increased RWT), eccentric LVH (increased LVMI andnormal RWT), and concentric LVH (increased LVMI and increased RWT). The right ventricle was assessed based on the American Society of Echocardiography (ASE) guidelines that include multiple linear measurements to estimate RV ventricular size, including measurements acquired in apical fourchamber, parasternal long-axis and parasternal short-axis views (17).

\section{Statistical analysis}

To compare the results between the experimental and control groups and/or two different patient groups, we used the Student's t-test for unpaired samples (with normal parameter value distribution) or Mann-Whitney U test (when normality in parameter distribution did not exist). Statistical analyzes were performed using the SPSS software package (version 16) at a significance level of $\mathrm{p}<$ 0.05 .

\section{RESULTS}

In terms of the demographic and clinical characteristics of the subjects, the study results showed that there were significant differences in body mass index (BMI) values, hematological and most biochemical parameters ( $p<0.01$ ), except for triglyceride levels, where no statistically significant difference between patient group and controls was found. There were also significant differences regarding the parameters related to the geometry and function of the myocardium (Table 1).

Our results showed that there were significantly higher concentrations of oxidative stress parameters, TBARS, AOPP, and sulfhydryl groups, in patients compared to controls $(p<0.01)$. Catalase activity showed decreased values in patients, however, this difference, compared to the control group, was not statistically significant $(\mathrm{p}=0.086$ ) (Table 2 ).

Correlation analysis of the investigated parameters of oxidative stress and myocardial status showed a strong positive correlation between geometry parameters and myocardial function, but also a significant positive correlation between intraventricular septum thickness and posterior wall thickness and plasma TBARS concentration. A significant negative correlation existed between the right ventricular diameter and catalase activity, as well as between plasma TBARS concentration and AOPP (Table 3). 
Table 1. Demographic, clinical and echocardiographic characteristics in patients with chronic heart failure (CHF) and controls

\begin{tabular}{|c|c|c|c|}
\hline & CHF Patients $(\mathrm{N}=81)$ & Controls $(\mathrm{N}=68)$ & Significance (p) \\
\hline & $X \pm S D$ & $X \pm S D$ & \\
\hline $\operatorname{BMI}\left(\mathrm{kg} / \mathrm{m}^{2}\right)$ & $27.93 \pm 2.84$ & $25.89 \pm 3.10$ & $<0.001$ \\
\hline Waist line $(\mathrm{cm})$ & $92.83 \pm 9.79$ & $92.15 \pm 6.71$ & 0.396 \\
\hline SBP (mmHg) & $126.53 \pm 15.83$ & $125.59 \pm 10.13$ & 0.817 \\
\hline $\mathrm{DBP}(\mathrm{mmHg})$ & $78.12 \pm 10.54$ & $79.41 \pm 2.37$ & 0.107 \\
\hline MAP (mmHg) & $93.66 \pm 11.61$ & $94.74 \pm 4.64$ & 0.306 \\
\hline $\mathrm{PP}(\mathrm{mmHg})$ & $47.91 \pm 9.12$ & $46.18 \pm 8.82$ & 0.256 \\
\hline \multicolumn{4}{|l|}{$\begin{array}{c}\text { Hematological and } \\
\text { biochemical parameters }\end{array}$} \\
\hline $\operatorname{RBC}\left(\times 10^{12} / 1\right)$ & $4.47 \pm 0.58$ & $4.70 \pm 0.35$ & $<0.005$ \\
\hline WBC $\left(\times 10^{9} / 1\right)$ & $8.02 \pm 1.99$ & $6.45 \pm 1.89$ & $<0.001$ \\
\hline $\mathrm{Hgb}(\mathrm{g} / \mathrm{l})$ & $135.69 \pm 16.46$ & $139.12 \pm 10.58$ & 0.096 \\
\hline CRP (mg/l) & $0.27 \pm 0.85$ & l & I \\
\hline Urea $(\mathrm{mmol} / \mathrm{l})$ & $8.68 \pm 5.00$ & $5.75 \pm 1.88$ & $<0.001$ \\
\hline Crea $(\mu \mathrm{mol} / \mathrm{l})$ & $119.76 \pm 69.56$ & $90.34 \pm 16.49$ & $<0.001$ \\
\hline eGFRcG (ml/min) & $72.33 \pm 22.34$ & $92.59 \pm 21.82$ & $<0.001$ \\
\hline Uric acid $(\mu \mathrm{mol} / \mathrm{l})$ & $388.54 \pm 94.38$ & $320.37 \pm 85.06$ & $<0.001$ \\
\hline Total cholesterol (mmol/1) & $4.71 \pm 1.31$ & $5.76 \pm 1.12$ & $<0.001$ \\
\hline LDL-C (mmol/l) & $2.94 \pm 1.01$ & $3.81 \pm 0.89$ & $<0.001$ \\
\hline HDL-C (mmol/l) & $1.04 \pm 0.24$ & $1.17 \pm 0.27$ & $<0.005$ \\
\hline TG (mmol/l) & $1.71 \pm 0.86$ & $1.91 \pm 1.12$ & 0.717 \\
\hline Glucosis (mmol/l) & $6.39 \pm 2.72$ & $5.42 \pm 1.13$ & $<0.005$ \\
\hline Fibrinogen $(\mathrm{g} / \mathrm{l})$ & $3.76 \pm 0.75$ & $3.13 \pm 0.63$ & $<0.001$ \\
\hline \multicolumn{4}{|l|}{$\begin{array}{c}\text { Echocardiography } \\
\text { parameters }\end{array}$} \\
\hline $\mathrm{EDD}(\mathrm{mm})$ & $58.66 \pm 7.05$ & $48.78 \pm 1.80$ & $<0.001$ \\
\hline $\mathrm{ESD}(\mathrm{mm})$ & $42.78 \pm 7.53$ & $33.03 \pm 2.95$ & $<0.001$ \\
\hline Septum (mm) & $11.81 \pm 1.38$ & $9.79 \pm 1.11$ & $<0.001$ \\
\hline $\mathrm{PW}(\mathrm{mm})$ & $10.51 \pm 1.33$ & $9.51 \pm 0.93$ & $<0.001$ \\
\hline $\mathrm{RV}(\mathrm{mm})$ & $26.40 \pm 3.45$ & $24.28 \pm 2.74$ & $<0.001$ \\
\hline Aortic root (mm) & $34.59 \pm 3.72$ & $32.21 \pm 3.16$ & $<0.001$ \\
\hline $\mathrm{LA}(\mathrm{mm})$ & $48.59 \pm 5.49$ & $39.06 \pm 2.49$ & $<0.001$ \\
\hline $\mathrm{E} / \mathrm{A}$ & $0.87 \pm 0.29$ & $1.08 \pm 0.11$ & $<0.001$ \\
\hline SPDK (mmHg) & $34.14 \pm 9.25$ & $25.38 \pm 3.77$ & $<0.001$ \\
\hline $\mathrm{HRV}$ (ms) & $105.96 \pm 37.88$ & $152.98 \pm 39.04$ & $<0.001$ \\
\hline LVMI $\left(\mathrm{g} / \mathrm{m}^{2}\right)$ & $140.70 \pm 29.10$ & $84.82 \pm 15.00$ & $<0.001$ \\
\hline LVMASS (g) & $276.57 \pm 59.11$ & $166.71 \pm 32.85$ & $<0.001$ \\
\hline
\end{tabular}

BMI, body mass index; SBP, systolic blood pressure; DBP, diastolic blood prassure; MAP, mean arterial pressure; PP, pulse pressure; RBC, red blood cells; WBC, white blod cells; HGb, haemoglobin; Crea, Creatinine; eGFRCG (ml/min), estimated glomerular filtration rate; LDL-C, low density lipoprotein; HDL, high density lipoprotein; EDD, Diastolic left ventricular diametar (mm); ESD, Systolic left ventricular diametar; Septum, Septal wall thikness (mm); PW, posterior wall thikness; RV, Right ventricular diameter; LA, left atrial; SPDK, systolic blood pressure right ventricle; HRV, heart rate variability; LVMI, mass index left ventricular; LVMass, left ventricular mass

$\mathrm{X} \pm \mathrm{SD}-$ mean \pm standard deviation; *-Mann Whitney U Test was used to compare the investigated groups 
Table 2. Parameters of oxidative stress in plasma in chronic heart failure (CHF) patients and controls

\begin{tabular}{c|c|c|c}
\hline \hline & $\begin{array}{c}\text { CHF Patients } \\
(\mathbf{N}=\mathbf{8 1})\end{array}$ & $\begin{array}{c}\text { Controls } \\
(\mathbf{N}=\mathbf{6 8})\end{array}$ & $\begin{array}{c}\text { Significance } \\
(\mathbf{p})\end{array}$ \\
\hline $\begin{array}{c}\mathrm{XBA} \mathbf{S D} \\
(\mu \mathrm{mol} / \mathrm{L})\end{array}$ & $19.47 \pm 7.37$ & $17.06 \pm 9.56$ & $<0.005$ \\
\hline $\begin{array}{c}\mathrm{CAT} \\
(\mathrm{U} / \mathrm{l})\end{array}$ & $68.86 \pm 31.72$ & $79.06 \pm 29.95$ & 0.086 \\
\hline $\begin{array}{c}\mathrm{AOPP} \\
(\mu \mathrm{mol} / \mathrm{mg})\end{array}$ & $98.52 \pm 26.52$ & $49.83 \pm 22.34$ & $<0.001$ \\
\hline $\begin{array}{c}\mathrm{SH} \\
(\mu \mathrm{mol} / \mathrm{L})\end{array}$ & $295.24 \pm 94.87$ & $215.24 \pm 94.01$ & $<0.001$ \\
\hline \hline
\end{tabular}

$\mathrm{X} \pm \mathrm{SD}-$ mean \pm standard deviation; *-Mann-Whitney $\mathrm{U}$ Test was used to compare the investigated groups

Table 3. Correlation of the echocardiography parameters and parameters of oxidative stress in patients with chronic heart failure

\begin{tabular}{c|c|c|c|c|c|c|c|c|c|c|c|c}
\hline \hline & Septum & PW & RV & $\begin{array}{c}\text { Aortic } \\
\text { root }\end{array}$ & LA & SPDK & LVMI & $\begin{array}{c}\text { LV } \\
\text { mass }\end{array}$ & TBARS & CAT & AOPP & SH \\
\hline EF & .180 & .171 & .052 & .138 & -.201 & -.154 & $-.508^{* *}$ & $-.467^{* *}$ & .048 & .046 & -.082 & .150 \\
\hline Septum & & $.545^{* *}$ & .109 & .151 & $.250^{*}$ & .183 & $.333^{* *}$ & $.373^{* *}$ & $.279^{*}$ & -.062 & -.112 & .076 \\
\hline PW & & & .094 & -.051 & .100 & .109 & $.331^{* *}$ & $.373^{* *}$ & $.265^{*}$ & -.013 & -.066 & -.013 \\
\hline RV & & & & $.221^{*}$ & $.411^{* *}$ & $.333^{* *}$ & .015 & .084 & -.032 & $-.246^{*}$ & -.028 & -.004 \\
\hline $\begin{array}{c}\text { Aortic } \\
\text { root }\end{array}$ & & & & & $.220^{*}$ & -.028 & -.022 & .005 & -.061 & -.149 & .002 & .167 \\
\hline LA & & & & & & $.555^{* *}$ & $.368^{* *}$ & $.379^{* *}$ & .039 & -.146 & .090 & .028 \\
\hline SPDK & & & & & & & .190 & .209 & .038 & -.003 & .091 & -.038 \\
\hline LVMI & & & & & & & $.941^{* *}$ & -.054 & .066 & .148 & -.068 \\
\hline LVmass & & & & & & & & & -.062 & .065 & .099 & -.038 \\
\hline TBARS & & & & & & & & & & .140 & $-.360^{* *}$ & .112 \\
\hline CAT & & & & & & & & & & & -.179 & .198 \\
\hline AOPP & & & & & & & & & & & & -.058 \\
\hline \hline
\end{tabular}

**: $\mathrm{p}<0.01$

*: $\mathrm{p}<0.05$

EF, Left ventricular ejection fraction (\%); Septum, Septal wall thikness (mm); PW, posterior wall thikness; RW, Right ventricular diameter; LA, left atrial; SPDK, systolic blood pressure right ventricle; IMLV, mass index left ventricular; LVMass, left ventricular mass

Analysis of BNP and oxidative stress parameters in patients with heart failure in relation to the type of ventricular hypertrophy or normal LV geometry showed that there were no significant differences in BNP concentration in terms of left ventricular geometry existence in subjects. TBARS concentration was significantly higher in patients with con- centric hypertrophy compared to patients with normal geometry $(\mathrm{p}<0.05)$. Catalase activity was statistically significantly lower in patients with concentric versus patients with eccentric hypertrophy $(p<0.05)$ (Table 4). In this case, the result of the only patient having concentric left ventricular remodeling was not considered. 
Table 4. BNP and oxidative stress parameters in chronic heart failure patients according to the left ventricular geometry

\begin{tabular}{|c|c|c|c|}
\hline & $\begin{array}{c}\text { Concentric } \\
\text { hypertrophy }(\mathrm{CH})\end{array}$ & $\begin{array}{c}\text { Eccentric } \\
\text { hypertrophy }(\mathrm{EH})\end{array}$ & $\begin{array}{c}\text { Normal } \\
\text { geometry (NG) }\end{array}$ \\
\hline & $X \pm S D$ & $X \pm S D$ & $X \pm S D$ \\
\hline $\begin{array}{l}\text { TBARS } \\
(\mu \mathrm{mol} / \mathrm{L})\end{array}$ & $\begin{array}{l}23.35 \pm 8.24^{\#} \\
21.67(14.87) \\
\end{array}$ & $\begin{array}{c}19.13 \pm 6.73 \\
16.66(10.31) \\
\end{array}$ & $\begin{array}{l}16.91 \pm 8.70 \\
14.17(7.72) \\
\end{array}$ \\
\hline $\begin{array}{l}\text { CAT } \\
(\mathrm{U} / \mathrm{L})\end{array}$ & $\begin{array}{c}53.03 \pm 20.40^{\# \#} \\
44.61(28.80)\end{array}$ & $\begin{array}{l}74.05 \pm 31.29 \\
72.58(52.53)\end{array}$ & $\begin{array}{l}60.36 \pm 32.71 \\
55.09(62.10)\end{array}$ \\
\hline $\begin{array}{c}\mathrm{AOPP} \\
(\mu \mathrm{mol} / \mathrm{mg})\end{array}$ & $\begin{array}{c}97.19 \pm 21.09 \\
102.69(34.49)\end{array}$ & $\begin{array}{c}98.06 \pm 27.63 \\
102.66(42.83)\end{array}$ & $\begin{array}{l}106.07 \pm 23.85 \\
106.85(24.20)\end{array}$ \\
\hline $\begin{array}{c}\mathrm{SH} \\
(\mu \mathrm{mol} / \mathrm{L})\end{array}$ & $\begin{array}{c}336.39 \pm 98.39 \\
380.54(163.58)\end{array}$ & $\begin{array}{l}285.81 \pm 97.97 \\
258.82(75.63) \\
\end{array}$ & $\begin{array}{c}301.65 \pm 72.59 \\
324.92(111.00)\end{array}$ \\
\hline BNP & $\begin{array}{c}137.13 \pm 209.36 \\
65.25(127.90)\end{array}$ & $\begin{array}{c}132.76 \pm 97.29 \\
124.70(153.30)\end{array}$ & $\begin{array}{c}80.63 \pm 73.31 \\
56.75(136.50)\end{array}$ \\
\hline
\end{tabular}

\#: CH vs. NG, $\mathrm{p}<0.05$

\#\#: CH vs. EH, p $<0.05$

\section{DISCUSSION}

Reference data indicate that oxidative stress is increased in patients with heart failure $(18,19)$. There are also assumptions that cardiac muscle itself is the source of free radicals (20). Reactive oxygen species (ROS) damage the heart by oxidizing lipids, proteins and DNA, thereby reducing cardiac contractility and ion transport impairment, especially calcium transport in cardiomyocytes. These toxic effects are reduced by the activity of the antioxidant system components.

The results of this study showed that there are significant differences in most biochemical parameters in patients with heart failure compared to controls. Interestingly, the concentrations of total cholesterol, LDL, and HDL also varied significantly: we observed lower concentrations of these parameters in patients. The reason for this phenomenon may be in the treatment of patients, since most patients with already diagnosed chronic heart failure have metabolic disorders, treated that occur in cardiovascular diseases, including hyperlipidemia for years. In contrast, some of the control group subjects were previously diagnosed with hyperlipidemia, hypertension, or hereditary predisposition to develop a cardiovascular event, but may not be treated at the same intensity as subjects with heart failure.

Heart failure is associated with increased oxidative stress, as indicated by our results. A scav- enger receptor for oxidized LDL (LOX-1) is expressed, among others, on endothelial cell surface, monocytes, smooth muscle cells, and cardiomyocytes (21). Binding of oxidized LDL to these receptors leads to the activation of NADPH oxidases, production of ROS, decreased expression of eNOS, and an increase in the tissue inflammation intensity. It is possible that this is one of the reasons why a decreased concentration of LDL is observed in patients compared to controls. An imbalance between NO and ROS levels also leads to endothelial dysfunction (22). A vicious circle may be involved there, and it probably begins with ischemia, when LOX-1 promotes the production of ROS, while ROS further increases the expression and activation of LOX-1, causing further an increasing loss of contractile myocardial function. Because of all these properties, LOX-1 is a novel target receptor in heart failure therapy. This could change the current approach that LDL levels should be reduced as much as possible in patients with this disease, and bring more importance to its effect on the receptor and therapeutical impairment of this effect.

The echocardiography parameters examined in this study as well as oxidative stress markers TBARS, AOPP, and $\mathrm{SH}$ groups showed significant differences in patients compared to controls. Other researchers have had similar results, which have shown that oxidative stress promotes many structural and functional changes, such as myocardial 
and ventricular remodeling and contractile and endothelial dysfunction, which are also the basic characteristics of heart failure $(3,23)$.

Protein oxidation end products (AOPP) have been shown to be a risk factor for atherosclerotic cardiovascular complications in dialysis patients and are associated with thickening of the carotid artery intima (24). This is an important fact for the study group in our research as patients had significantly higher serum urea and creatinine values and significantly lower eGFR compared to controls. Liu et al. have shown that an increase in AOPP concentration correlates with an increase in atherosclerotic plaques in rabbits with hypercholesterolemia (25).

Many reference data point out to significantly higher concentrations of MDA in NYHA Class III and IV heart failure and their correlation with the intensity of contractile dysfunction and left ventricular dilation $(3,26)$. This increase in the concentration of lipid peroxidation markers was accompanied by a decrease in circulating antioxidant levels $(18,27)$, an increase in SOD activity and a decrease in GPx activity $(3,18,27)$. Such findings are partly consistent with our results. Namely, in our subjects, there was no significant difference in the activity of catalase, one of the most important enzyme of the antioxidant protection system, among the studied groups. The activity of this enzyme differed significantly in the group of patients in relation to the type of myocardial hypertrophy (catalase activity was higher in patients with concentric hypertrophy). Diaz-Velez et al. showed that patients with cardiac insufficiency have significantly higher plasma MDA concentrations than controls, and that MDA levels correlate with the duration of heart failure (28). Belch et al. showed a significant negative correlation between MDA and left ventricular ejection fraction $(\mathrm{r}=-0.35)(19)$.

The correlation analysis of the parameters we examined did not show such results. The TBARS correlated significantly positively only with septum thickness and posterior wall in systole.

Literature data indicate that there is an increased production of ROS in the damaged myocardium, which is directly proportional to the degree of left ventricular dysfunction (20,29). Lipid peroxidation as an index of oxidative stress is reduced in the hypertrophied heart. An increase in antioxidants and a decrease in lipid peroxidation have been showed in rat hearts 10 weeks after inducing hypertrophy (30). This literature data is inconsistent with the results of our study (significantly higher TBARS concentration in patients with concentric hypertrophy than subjects with normal heart geometry), probably because besides hypertrophy of the heart, our patients had other associated conditions, which makes it impossible to compare the animal model studies results in the references equally.

Amir et al concluded that markers of oxidative stress correlate positively with clinical parameters of heart failure and that their high concentrations represent poor prognostic factors for disease outcome, as well as being associated with renal function and concentrations of hsCRP and proBNP (31). Karabacak et al. showed that the oxidative stress index was significantly elevated in patients with HF compared to the control group, and that there was a positive correlation of this parameter with left ventricular end-systolic volume, uric acid concentration and total oxidative stress level, whereas it was negative with total antioxidative capacity (TAC) and ejection fraction (32).

In our study, the BNP value was determined only in the group of patients with chronic heart failure, and showed no significant variation concerning the type of left ventricular geometry. $\mathrm{Ng}$ et al concluded that measurement of CRP and myeloperoxidase activity increases the specificity of NTproBNP in the case of diagnosis of left ventricular dysfunction (33).

Parallel measurement and monitoring of multiple biomarkers of heart failure, with adequate clinical observation of the patient, may be helpful in assessing the risk of heart failure and the possible development of other cardiovascular events (34). Our results indicate that BNP is probably not related to the specific form and shape of cardiac muscle geometry alteration in this disease, while some of the parameters of oxidative stress are likely to be. The explanation for this phenomenon lies in the detailed pathophysiology of the change in myocardial shape and structure during the development of myocardial dysfunction which originates in an inflammation process and its consequences.

\section{CONCLUSION}

The results of this study show that oxidative stress parameters are significantly elevated in patients with heart failure, and that concentrations of TBARS and AOPP, markers of lipid and protein oxidation, 
have a strong correlation. TBARS concentration correlates positively with both myocardial wall thickness and wall thickening during systole. When observing the results of oxidative stress parameters in comparison to the type of cardiac geometry, we concluded that TBARS is significantly higher in patients with concentric hypertrophy than those with unchanged cardiac geometry. Catalase activity was also higher in subjects with concentric hypertrophy than those with eccentric.

\section{Acknowledgment}

This work was supported by the Ministry of Education, Science and Technological Development, Republic of Serbia project number 41018.

\section{Conflict of interests}

Authors report no conflicts of interest.

\section{References}

1. Ponikowski P, Anker SD, AlHabib KF et al. Heart failure: preventing disease and death worldwide. ESC Heart Fail 2014;1:4-25. https://doi.org/10.1002/ehf2.12005

2. Tsutsui H, Kinugawa S, Matsushima S. Oxidative stress and heart failure 2011; Am J Physiol Heart Circ Physiol 301: H2181-H2190. https://doi.org/10.1152/ajpheart.00554.2011

3. Keith M, Geranmayegan A, Sole MJ et al. Increased Oxidative Stress in Patients With Congestive Heart Failure. J Am Coll Cardiol 1998;31(6):1352-6. https://doi.org/10.1016/S0735-1097(98)00101-6

4. Nishiyama $\mathrm{Y}$, Ikeda $\mathrm{H}$, Haramaki $\mathrm{N}$ et al. Oxidative stress is related to exercise intolerance in patients with heart failure. Am Heart J 1998;135:115-20. https://doi.org/10.1016/S0002-8703(98)70351-5

5. Gao Wei Dong, Liu Yongge, Marban Eduardo. Selective Effects of Oxygen Free Radicals on Excitation-Contraction Coupling in Ventricular Muscle. Circulation 1996;94:2597-604. https://doi.org/10.1161/01.CIR.94.10.2597
6. Grieve D. Oxidative stress in heart failure More than just damage. Eur Heart J 2003;24:2161-3. https://doi.org/10.1016/j.ehj.2003.10.015

7. Nakamura K, Fushimi K, Kouchi $\mathrm{H}$ et al. Inhibitory Effects of Antioxidants on Neonatal Rat Cardiac Myocyte Hypertrophy Induced by Tumor Necrosis Factor- $\alpha$ and Angiotensin II. Circulation 1998;98:794-9.

https://doi.org/10.1161/01.CIR.98.8.794

8. Witko-Sarsat V, Gausson V, Nguyen A-T et al. AOPP-induced activation of human neutrophil and monocyte oxidative metabolism: A potential target for $\mathrm{N}$-acetylcysteine treatment in dialysis patients. Kidney Int 2003;64:82-91. https://doi.org/10.1046/j.1523-1755.2003.00044.x

9. Levey AS, Bosch JP, Lewis JB et al. A More Accurate Method To Estimate Glomerular Filtration Rate from Serum Creatinine: A New Prediction Equation. Ann Intern Med 1999; 130:461-70. https://doi.org/10.7326/0003-4819-130-6199903160-00002

10. Andreeva IL, Kožemjakin AL, Kiškun AA. Modification of the method of measurement of 
lipid peroxides in test with thiobarbituric acid Lab Delo 1988:41-3.

11. Ellman LG. Tissue sulphydril groups. Arch Biochem Biophys 1952:70-7. https://doi.org/10.1016/0003-9861(59)90090-6

12. Góth L. A simple method for determination of serum catalase activity and revision of reference range. Clin Chim Acta 1991;196:143-51. https://doi.org/10.1016/0009-8981(91)90067-M

13. Witko-Sarsat V, Friedlander M, Capeillère-Blandin $\mathrm{C}$ et al. Advanced oxidation protein products as a novel marker of oxidative stress in uremia. Kidney Int 1996;49:1304-13.

https://doi.org/10.1038/ki.1996.186

14. Feigenbaum H. Echocardiography. Fifth edition. Philadelphia. Lee\&Fabiger: 1994.

15. Lorell B, Carabello B. Left ventricular hypertrophy: pathogenesis, detection and prognosis. Circulation 2000; 102:470-9.

https://doi.org/10.1161/01.CIR.102.4.470

16. Devereux RB, Alonso DR, Lutas EM et al. Echocardiographic assessment of left ventricular hypertrophy:comparison to necropsy findings. Am J Cardiol 1986; 57:450-8.

https://doi.org/10.1016/0002-9149(86)90771-X

17. Lang RM, Bierig M, Devereux RB et al. Chamber Quantification Writing Group; American Society of Echocardiography's Guidelines and Standards Committee; European Association of Echocardiography. Recommendations for chamber quantification: a report from the American Society of Echocardiography's Guidelines and Standards Committee and the Chamber Quantification Writing Group, developed in conjunction with the European Association of Echocardiography, a branch of the European Society of Cardiology. J Am Soc Echocardiogr 2005; 18:1454-7. https://doi.org/10.1016/j.echo.2005.10.005

18. McMurray J, Chopra M, Abdullah I et al. Evidence of oxidative stress in chronic heart failure in humans. Eur Heart J 1993;14:1493-8. https://doi.org/10.1093/eurhearti/14.11.1493
19. Belch JJ, Bridges $A B$, Scott $N$ et al. Oxygen free radicals and congestive heart failure. Heart 1991;65:245-8.

https://doi.org/10.1136/hrt.65.5.245

20. Ide T, Tsutsui H, Kinugawa $\mathrm{S}$ et al. Direct Evidence for Increased Hydroxyl Radicals Originating From Superoxide in the Failing Myocardium. Circ Res 2000;86:152-7.

https://doi.org/10.1161/01.RES.86.2.152

21. Mitra S, Goyal T, Mehta JL. Oxidized LDL, LOX-1 and Atherosclerosis. Cardiovasc Drugs Ther 2011;25:419-29.

https://doi.org/10.1007/s10557-011-6341-5

22. Sugimoto $\mathrm{K}$, Ishibashi $\mathrm{T}$, Sawamura $\mathrm{T}$ et al. LOX1-MT1-MMP axis is crucial for RhoA and Rac1 activation induced by oxidized low-density lipoprotein in endothelial cells. Cardiovasc Res 2009;84:127-36.

https://doi.org/10.1093/cvr/cvp177

23. Koba S, Gao Z, Sinoway LI. Oxidative stress and the muscle reflex in heart failure: Tempol reduces sympathetic nerve response to contraction in HF. J Physiol 2009;587:5227-37.

https://doi.org/10.1113/jphysiol.2009.177071

24. Zhou Q, Wu S, Jiang, et al. Accumulation of circulating advanced oxidation protein products is an independent risk factor for ischaemic heart disease in maintenance haemodialysis patients: AOPP and IHD in haemodialysis. Nephrology 2012;17:642-9.

https://doi.org/10.1111/j.1440-1797.2012.01640.x

25. Liu SX, Hou FF, Guo ZJ et al. Advanced Oxidation Protein Products Accelerate Atherosclerosis Through Promoting Oxidative Stress and Inflammation. ATVB 2006;26:1156-62. https://doi.org/10.1161/01.ATV.0000214960.85469.68

26. Radovanovic S, Krotin M, Simic DV et al. Markers of oxidative damage in chronic heart failure: role in disease progression. Redox Rep 2008;13:109-16. https://doi.org/10.1179/135100008X259204

27. Radovanovic S, Savic-Radojevic A, PljesaErcegovac $\mathrm{M}$ et al. Markers of Oxidative Damage and Antioxidant Enzyme Activities as Predictors 
of Morbidity and Mortality in Patients With Chronic Heart Failure. J Card Fail 2012;18:493-501. https://doi.org/10.1016/j.cardfail.2012.04.003

28. Díaz-Vélez CR, García-Castiñeiras S, MendozaRamos E et al. Increased malondialdehyde in peripheral blood of patients with congestive heart failure. Am Heart J 1996;131:146-52.

https://doi.org/10.1016/S0002-8703(96)90063-0

29. Cesselli D, Jakoniuk I, Barlucchi L, Beltrami AP, Hintze TH, Nadal-Ginard B, et al. Oxidative Stress-Mediated Cardiac Cell Death Is a Major Determinant of Ventricular Dysfunction and Failure in Dog Dilated Cardiomyopathy. Circ Res 2001;89:279-86.

https://doi.org/10.1161/hh1501.094115

30. Singh N, Dhalla AK, Seneviratne $C$ et al. Oxidative stress and heart failure. Mol Cell Biochem 1995;147:77-81. https://doi.org/10.1007/BF00944786

31. Amir O, Paz H, Rogowski $\mathrm{O}$ et al. Serum Oxidative Stress Level Correlates with Clinical
Parameters in Chronic Systolic Heart Failure Patients. Clin Cardiol 2009;32:199-203. https://doi.org/10.1002/clc.20317

32. Karabacak M, Dogan A, Tayyar S et al. Oxidative Stress Status Increase in Patients with Nonischemic Heart Failure. Med Princ Pract 2014;23:532-7. https://doi.org/10.1159/000365512

33. Ng LL, Pathik B, Loke IW et al. Myeloperoxidase and C-reactive protein augment the specificity of Btype natriuretic peptide in community screening for systolic heart failure. Am Heart J 2006;152:94101.

https://doi.org/10.1016/j.ahj.2005.09.020

34. Szczurek W, Szyguła-Jurkiewicz B. Oxidative stress and inflammatory markers - the future of heart failure diagnostics Kardiochir Torakochirurgia Pol 2015;2:145-9.

https://doi.org/10.5114/kitp.2015.52856 


\title{
Korelacija parametara oksidativnog stresa i geometrije leve komore kod bolesnika sa hroničnom srčanom insuficijencijom
}

\author{
Sandra Šarić1 , Tatjana Cvetković2,3, Dejan Petrović1,4, Valentina Mitić1, Sanja Stojanović1, \\ Vladana Stoiljković3 ${ }^{3}$ Marina Deljanin-Ilić, ${ }^{1,4}$ \\ ${ }^{1}$ Institut za tretman i rehabilitaciju "Niška Banja", Niška Banja, Srbija \\ ${ }^{2}$ Univerzitet u Nišu, Medicinski fakultet, Institut za biohemiju, Niš, Srbija \\ ${ }^{3}$ Centar za medicinsku i kliničku biohemiju, Klinički centar, Niš, Srbija \\ ${ }^{4}$ Univerzitet u Nišu, Medicinski fakultet, Niš, Srbija
}

\section{S AŽETAK}

Oksidativni stres, kao jedan od patofizioloških mehanizama koji učestvuju u smanjenju kontraktilnosti miokarda, stimuliše proliferaciju srčanih fibroblasta i aktiviranje matriksnih metaloproteinaza, što dovodi do remodelovanja vanćelijskog matriksa. Hipertrofija leve komore (LVH) je poznati nezavisni faktor rizika za kardiovaskularne događaje.

Cilj ovog istraživanja bio je utvrditi vezu između parametara oksidativnog stresa i pokazatelja geometrije leve komore kod bolesnika sa hroničnom srčanom insuficijencijom.

Studija je obuhvatila 81 ispitanika s dijagnozom srčane insuficijencije i 68 ispitanika raspoređenih $u$ kontrolnu grupu. Parametri morfologije miokarda i funkcije leve komore mereni su ehokardiografijom. Sadržaj supstanci, koje reaguju sa tiobarbiturnom kiselinom (TBARS), krajnji produkti oksidacije proteina (AOPP), ukupne SH grupe u serumu i aktivnost katalaze određivani su u obe grupe. Rezultati su pokazali da su koncentracije TBARS, AOPP i SH grupa značajno povećani kod bolesnika u poređenju sa ispitanicima iz kontrolne grupe $(\mathrm{p}<0,01)$, uz istovremeno povećanu koncentraciju TBARS kod bolesnika sa koncentričnom hipertrofijom $u$ poređenju sa bolesnicima sa normalnom geometrijom $(p<0,05)$. Korelaciona analiza pokazala je snažnu pozitivnu povezanost geometrijskih parametara i funkcije miokarda i TBARS i negativnu korelaciju između dijametra desne komore i aktivnosti katalaze.

Rezultati ove studije pokazuju da su parametri oksidativnog stresa značajno povišeni kod bolesnika sa oštećenjem srca i da koncentracije TBARS i AOPP, markera oksidacije lipida i proteina, snažno koreliraju sa parametrima geometrije leve komore.

Ključne reči: hronično oštećenje srca, oksidativni stres, geometrija leve komore 